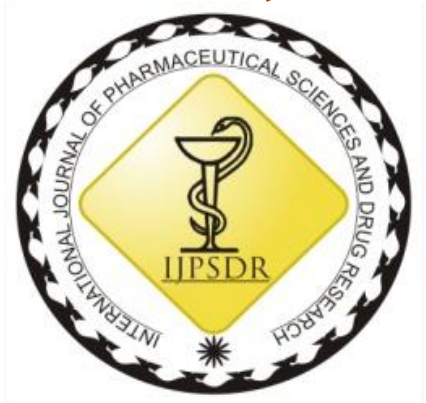

ISSN: 0975-248X

Research Article CODEN (USA): IJPSPP

(c) BY-NC-SA

\title{
A Highly Validated RP-HPLC Method Development for the Simultaneous Estimation of Dapagliflozin and Saxagliptin in Tablet Dosage Forms
}

\author{
B. Reddy Padmaja', B. Sivagami ${ }^{1 *}$, R. Chandrasekar ${ }^{2}$, M. Niranjan babu ${ }^{2}$ \\ ${ }^{1}$ Department of Pharmaceutical Analysis, Seven Hills College of Pharmacy, Venkataramapuram, Tirupati, Chitoor Dist, \\ 517561, Andhra Pradesh, India \\ 2Department of Pharmacognosy, Seven Hills College of Pharmacy, Venkataramapuram, Tirupati, Chitoor Dist, 517561, \\ Andhra Pradesh, India
}

Copyright ( 2018 B. Reddy Padmaja et al. This is an open access article distributed under the terms of the Creative Commons AttributionNonCommercial-ShareAlike 4.0 International License which allows others to remix, tweak, and build upon the work non-commercially, as long as the author is credited and the new creations are licensed under the identical terms.

\begin{abstract}
A simple, accurate, precise method was developed for the simultaneous estimation of Dapagliflozin and Saxagliptin in Tablet dosage form. Chromatogram was run through Standard BDS C8 column $(50 \times 4.6 \mathrm{~mm}, 5 \mu)$ The Mobile phase containing Potassium dihydrogen phosphate: Acetonitrile in the ratio 55:45, pH was adjusted to 3.8 with dilute orthophosphoric acid. The solution was pumped through the column at a flow rate of 1 $\mathrm{ml} / \mathrm{min}$. The column temperature was maintained at $30^{\circ} \mathrm{C}$. Optimized wavelength selected was $210 \mathrm{~nm}$. Retention time of Dapagliflozin and Saxagliptin were found to be $2.266 \mathrm{~min}$ and $2.805 \mathrm{~min}$. \% RSD of the Dapagliflozin and Saxagliptin were found to be 0.5 and 0.5 respectively. \% Recovery was obtained as $98.98 \%$ and 98.72\% for Dapagliflozin and Saxagliptin respectively. LOD, LOQ values obtained from regression equations of Dapagliflozin and Saxagliptin were 0.20, 0.60 and 0.26, 0.79 respectively. Regression equation of Dapagliflozin is $y=37377 x+89244$, and $y=12254 x+3122$ of Saxagliptin. The retention times were decreased so that the run time also decreased. So the method developed was simple and economical that can be applied successfully for simultaneous estimation of both Dapagliflozin and Saxagliptin in bulk and combined tablet formulation.
\end{abstract}

Keywords: Dapagliflozin, Saxagliptin, RP-HPLC, Validation, Simultaneous estimation.

*Corresponding author: Mrs. B. Sivagami

Address: Department of Pharmaceutical Analysis, Seven Hills College of Pharmacy, Venkataramapuram, Tirupati, Chitoor Dist, 517561, Andhra Pradesh, India

Tel.: +91-8297908154

E-mail $\bowtie$ : sivagamib_27@rediffmail.com

Relevant conflicts of interest/financial disclosures: The authors declare that the research was conducted in the absence of any commercial or financial relationships that could be construed as a potential conflict of interest.

Received: 11 July, 2018; Revised: 20 August, 2018; Accepted: 22 August, 2018; Published: 23 September, 2018

\section{INTRODUCTION}

Dapagliflozin is a sodium-glucose co-transporter 2 (SGLT2) inhibitor used as an adjunct to diet and exercise to improve glycemic control in adults with type 2 diabetes mellitus. Dapagliflozin is chemically called as (2S, 3R, 4R, 5S, 6R)-2-[4-chloro-3-(4- 
ethoxybenzyl) phenyl]-6-(hydroxymethyl) tetrahydro$2 \mathrm{H}$ pyran-3, 4, 5-triol as shown in (figure 1). Common side effects include yeast infections of the vagina or penis, urinary tract infections, and changes in urination, including urgent need to urinate more often, in larger amounts, or at night. [1-9]

Dapagliflozin inhibits subtype 2 of the sodium-glucose transport proteins (SGLT2), which is responsible for at least $90 \%$ of the glucose reabsorption in the kidney. Blocking this transporter causes blood glucose to be eliminated through the urine. The efficacy of this medication class has yet to be determined, but in initial clinical trials, Dapagliflozin lowers $\mathrm{HbA}_{1 \mathrm{c}}$ by 0.90 percentage points when added to metformin. ${ }^{[1-9]}$

Saxagliptin, is a new oral hypoglycemic (anti-diabetic drug) of the new dipeptidyl peptidase-4 (DPP-4) inhibitor class of drugs. Saxagliptin is chemically called as $\quad(1 S, \quad 3 S, \quad 5 S)-2-[(2 S)-2-a m i n o-2-(3-h y d r o x y-1-$ adamantyl) acetyl]-2-azabicyclo [3.1.0] hexane-3carbonitrile as shown in (figure 2.) $[1,10,11]$

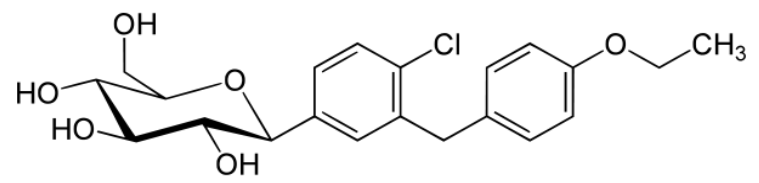

Fig. 1: Structure of Dapagliflozin

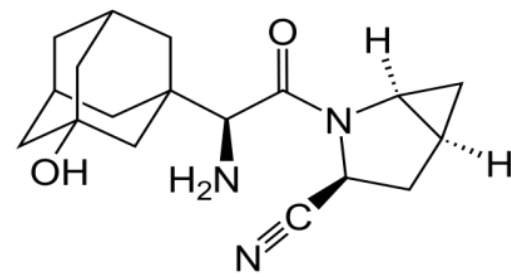

Fig. 2: Structure of Saxagliptin

Saxagliptin is a dipeptidyl peptidase-4 (DPP-4) inhibitor antidiabetic for the treatment of type 2 diabetes. DPP-4 inhibitors are a class of compounds that work by affecting the action of natural hormones in the body called incretins. Incretins decrease blood sugar by increasing consumption of sugar by the body, mainly through increasing insulin production in the pancreas, and by reducing production of sugar by the liver. [Bristol-Myers Squibb Press Release] DPP-4 is a membrane associated peptidase which is found in many tissues, lymphocytes and plasma. DPP-4 has two main mechanisms of action, an enzymatic function and another mechanism where DPP-4 binds adenosine deaminase, which conveys intracellular signals via dimerization when activated. Saxagliptin forms a reversible, histidine-assisted covalent bond between its nitrile group and the S630 hydroxyl oxygen on DPP-4. The inhibition of DPP-4 increases levels active of glucagon like peptide 1 (GLP-1), which inhibits glucagon production from pancreatic alpha cells and increases production of insulin from pancreatic beta cells. $[1,10,11]$

The literature review revealed that several analytical methods have been reported for Dapagliflozin and
Saxagliptin in UV-Spectrophotometry, RP-HPLC, individually and in combination. This research work implicates the simultaneous estimation of Dapagliflozin and Saxagliptin by RP-HPLC in tablet dosage forms. This present study reports simultaneous estimation of Dapagliflozin and Saxagliptin by RP-HPLC in tablet dosage form. [12-18]

\section{MATERIALS AND METHODS \\ Materials}

Dapagliflozin and Saxagliptin pure drugs (API), Combination Dapagliflozin and Saxagliptin tablets (QTERN), Distilled water, Acetonitrile, Phosphate buffer, Methanol, Potassium dihydrogen phosphate buffer, Ortho-phosphoric acid. All the above chemicals and solvents were obtained from Rankem.

\section{Instruments}

Electronics Balance-Denver, $\mathrm{pH}$ meter-BVK enterprises, India, Ultrasonicator-BVK enterprises, WATERS HPLC 2695 SYSTEM equipped with quaternary pumps, Photo Diode Array detector and Auto sampler integrated with Empower 2 Software. UV-VIS spectrophotometer PG Instruments T60 with special bandwidth of $2 \mathrm{~mm}$ and $10 \mathrm{~mm}$ and matched quartz cells integrated with UV win 6 Software was used for measuring absorbances of Dapagliflozin and Saxagliptin solutions.

\section{Methods}

Diluent: Based up on the solubility of the drugs, diluent was selected, Acetonitrile and Water taken in the ratio of 50:50.

Preparation of Standard stock solutions: Accurately weighed $10 \mathrm{mg}$ of Dapagliflozin, $5 \mathrm{mg}$ of Saxagliptin and transferred to individual $10 \mathrm{ml}$ volumetric flasks separately. $3 / 4^{\text {th }}$ of diluents was added to both of these flasks and sonicated for 10 minutes. Flasks were made up with diluents and labeled as Standard stock solution 1 and $2(1000 \mu \mathrm{g} / \mathrm{ml}$ of Dapagliflozin and $500 \mu \mathrm{g} / \mathrm{ml}$ of Saxagliptin).

Preparation of Standard working solutions (100\% solution): $1 \mathrm{ml}$ from each stock solution was pipetted out and taken into a $10 \mathrm{ml}$ volumetric flask and made up with diluent $(100 \mu \mathrm{g} / \mathrm{ml}$ Dapagliflozin of and $50 \mu \mathrm{g} / \mathrm{ml}$ of Saxagliptin).

Preparation of Sample stock solutions: 5 tablets were weighed and the average weight of each tablet was calculated, then the weight equivalent to 1 tablet was transferred into a $10 \mathrm{ml}$ volumetric flask, $5 \mathrm{ml}$ of diluents was added and sonicated for $25 \mathrm{~min}$, further the volume was made up with diluent and filtered by HPLC filters $(1000 \mu \mathrm{g} / \mathrm{ml}$ of Dapagliflozin and $500 \mu \mathrm{g} / \mathrm{ml}$ of Saxagliptin).

Preparation of Sample working solutions (100\% solution): $1 \mathrm{ml}$ of filtered sample stock solution was transferred to $10 \mathrm{ml}$ volumetric flask and made up with diluent $(100 \mu \mathrm{g} / \mathrm{ml}$ of Dapagliflozin and $50 \mu \mathrm{g} / \mathrm{ml}$ of Saxagliptin).

Preparation of buffer

0.01N $\mathrm{KH}_{2} \mathrm{PO}_{4}$ Buffer: Accurately weighed $1.36 \mathrm{~g}$ of Potassium dihyrogen phosphate in a $1000 \mathrm{ml}$ of 

added and degassed to sonicate and finally make up the volume with water then $1 \mathrm{ml}$ of Triethylamine was
Volumetric flask add about $900 \mathrm{ml}$ of milli-Q water

added and then $\mathrm{pH}$ was adjusted to 3.8 with dil. Orthophosphoric acid solution.

Method development

Method development was done by changing various, mobile phase ratios, buffers etc.

\begin{tabular}{|c|c|c|c|c|c|c|}
\hline Parameters & Trial 1 & Trial 2 & Trial 3 & Trial 4 & Trial 5 & $\begin{array}{l}\text { Optimized } \\
\text { Method }\end{array}$ \\
\hline Mobile phase & $\begin{array}{c}\text { Water and } \\
\text { Methanol } \\
(50: 50)\end{array}$ & $\begin{array}{c}\text { Water: } \\
\text { Acetonitrile } \\
(50: 50)\end{array}$ & $\begin{array}{c}0.01 \mathrm{~N} \mathrm{KH}_{2} \mathrm{PO}_{4} \\
\text { (4.8):Acetonitr } \\
\text { ile }(50: 50)\end{array}$ & $\begin{array}{c}60 \% \text { OPA } \\
\text { buffer: } 40 \% \\
\text { Acetonitrile }\end{array}$ & $\begin{array}{c}55 \% 0.1 \% \\
\text { OPA } \\
\text { buffer:45\% } \\
\text { Acetonitrile }\end{array}$ & $\begin{array}{c}55 \% \text { buffer: } \\
45 \% \\
\text { Acetonitrile }\end{array}$ \\
\hline Flow rate & $1 \mathrm{ml} / \mathrm{min}$ & $1 \mathrm{ml} / \mathrm{min}$ & $1 \mathrm{ml} / \mathrm{min}$ & $1 \mathrm{ml} / \mathrm{min}$ & $1 \mathrm{ml} / \mathrm{min}$ & $1 \mathrm{ml} / \mathrm{min}$ \\
\hline Column & $\begin{array}{c}\text { Discovery C18 } \\
(4.6 \times 250 \mathrm{~mm}, \\
5 \mu \mathrm{m})\end{array}$ & $\begin{array}{c}\text { Discovery C18 } \\
(4.6 \times 250 \mathrm{~mm}, \\
5 \mu \mathrm{m})\end{array}$ & $\begin{array}{c}\text { Discovery C18 } \\
(4.6 \times 250 \mathrm{~mm}, \\
5 \mu \mathrm{m})\end{array}$ & $\begin{array}{c}\text { ODS C18 }(4.6 \\
\times 250 \mathrm{~mm}, \\
5 \mu \mathrm{m})\end{array}$ & $\begin{array}{c}\text { BDSC18 }(4.6 \\
\times 150 \mathrm{~mm}, \\
5 \mu \mathrm{m})\end{array}$ & $\begin{array}{c}\text { BDSC8 }(4.6 \times \\
150 \mathrm{~mm}, 5 \mu \mathrm{m})\end{array}$ \\
\hline $\begin{array}{l}\text { Detector wave } \\
\text { length }\end{array}$ & $210 \mathrm{~nm}$ & $210 \mathrm{~nm}$ & $210 \mathrm{~nm}$ & $210 \mathrm{~nm}$ & $210 \mathrm{~nm}$ & $210 \mathrm{~nm}$ \\
\hline Column Temp & $30^{\circ} \mathrm{C}$ & $30^{\circ} \mathrm{C}$ & $30^{\circ} \mathrm{C}$ & $30^{\circ} \mathrm{C}$ & $30^{\circ} \mathrm{C}$ & $30^{\circ} \mathrm{C}$ \\
\hline $\begin{array}{l}\text { Injection } \\
\text { volume }\end{array}$ & $10 \mu \mathrm{L}$ & $10 \mu \mathrm{L}$ & $10 \mu \mathrm{L}$ & $10 \mu \mathrm{L}$ & $10 \mu \mathrm{L}$ & $10 \mu \mathrm{L}$ \\
\hline Run time & $8.0 \mathrm{~min}$ & $14 \min$ & $10 \mathrm{~min}$ & $10 \mathrm{~min}$ & $10 \mathrm{~min}$ & $6 \mathrm{~min}$ \\
\hline Diluent & $\begin{array}{l}\text { Water and } \\
\text { Acetonitrile in } \\
\text { the ratio 50:50 }\end{array}$ & $\begin{array}{l}\text { Water and } \\
\text { Acetonitrile in } \\
\text { the ratio } 50: 50\end{array}$ & $\begin{array}{l}\text { Water and } \\
\text { Acetonitrile in } \\
\text { the ratio 50:50 }\end{array}$ & $\begin{array}{l}\text { Water and } \\
\text { Acetonitrile in } \\
\text { the ratio } 50: 50\end{array}$ & $\begin{array}{c}\text { Water and } \\
\text { Acetonitrile } \\
\text { in the ratio } \\
50: 50\end{array}$ & $\begin{array}{l}\text { Water and } \\
\text { Acetonitrile in } \\
\text { the ratio 50:50 }\end{array}$ \\
\hline
\end{tabular}

Optimization of chromatographic conditions

Trials Results

Trial 1 Dapagliflozin was not eluted, so further trial was carried out.

Trial 2 Both peaks were eluted but peak shapes are not good So, Further trial was carried out.

Trial 3 Dapagliflozin Saxagliptin both peak are eluted but Saxagliptin peak having tailing, Dapagliflozin having lees plate count and fronting so, further trial was carried out.

Trial 4 Dapagliflozin \& Saxagliptin both peak are eluted but Dapagliflozin was eluted at void time, peak shapes were not goo and base line is not good so, further trail was carried out.

Trial 5 Both peaks were eluted, but both peaks having fronting So further trial was carried out.

Optimized Both peaks have good resolution, tailing method Factor, theoretical plate count and resolution.

\section{RESULTS AND DISCUSSION}

Observation: Dapagliflozin and Saxagliptin were eluted at $2.266 \mathrm{~min}$ and $2.805 \mathrm{~min}$ respectively with good resolution. Plate count and tailing factor was very satisfactory, so this method was optimized and to be validated (Fig. 3).

System suitability: All the system suitability parameters were within the range and satisfactory as per ICH guidelines ${ }^{[12]}$ (Table 1 and Fig. 4).
Linearity: Six linear concentrations of Dapagliflozin $(25-150 \mu \mathrm{g} / \mathrm{ml})$ and Saxagliptin $(12.5-75 \mu \mathrm{g} / \mathrm{ml})$ were injected in a duplicate manner. Average areas were mentioned above and linearity equations obtained for Dapagliflozin was $y=37377 x+89244$ and of Saxagliptin was $y=12254 x+3122$ Correlation coefficient obtained was 0.999 for the two drugs (Table 2 and Fig. 5 \& 6).

Precision: From a single volumetric flask of working standard solution six injections were given and the obtained areas were mentioned above. Average area, standard deviation and \% RSD were calculated for two drugs. \% RSD obtained as $0.6 \%$ and $0.2 \%$ respectively for Dapagliflozin and Saxagliptin (Table 3).

System Precision: Table 3.

Repeatability: Average area, standard deviation and \% RSD were calculated for two drugs and obtained as $0.5 \%$ and $0.5 \%$ respectively for Dapagliflozin and Saxagliptin (Table 4).

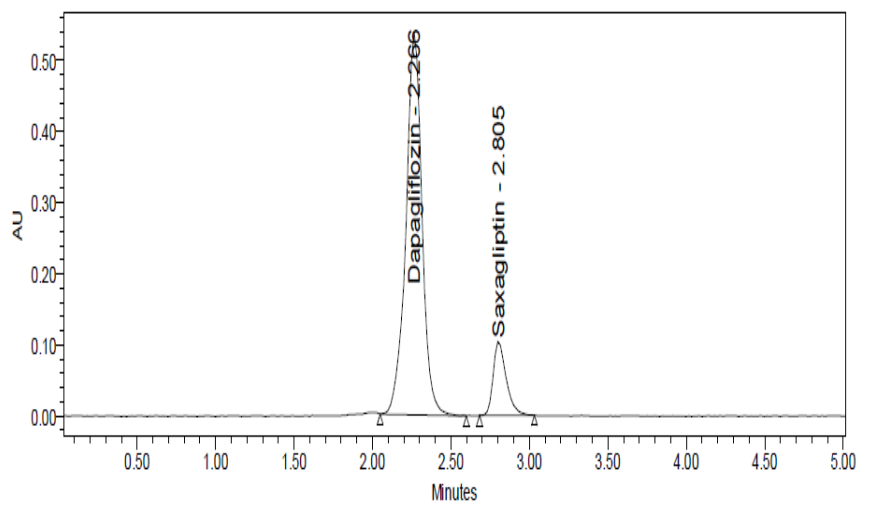

Fig. 3: Optimized chromatogram 
B. Reddy Padmaja et al. / A Highly Validated RP-HPLC Method Development for the Simultaneous.

Table 1: System suitability parameters for Dapagliflozin and Saxagliptin

\begin{tabular}{cccccccc}
\hline S. No & \multicolumn{3}{c}{ Dapagliflozin } & \multicolumn{3}{c}{ Saxagliptin } \\
\hline Inj & RT(min) & USP Plate Count & Tailing & RT(min) & USP Plate Count & Tailing & Resolution \\
\hline 1 & 2.257 & 2619 & 0.98 & 2.802 & 5618 & 1.33 & 1.34 \\
2 & 2.261 & 2727 & 0.97 & 2.803 & 5730 & 1.39 & 1.6 \\
3 & 2.266 & 2751 & 0.97 & 2.803 & 5286 & 1.41 & 1.7 \\
4 & 2.270 & 2598 & 0.96 & 2.803 & 4994 & 1.31 & 1.6 \\
5 & 2.272 & 2561 & 1.03 & 2.804 & 5144 & 1.37 \\
6 & 2.275 & 2530 & 1.01 & 2.805 & 5772 & 1.6 \\
\hline
\end{tabular}

Table 2: Linearity table for Dapagliflozin and Saxagliptin

\begin{tabular}{cccc}
\hline \multicolumn{2}{c}{ Dapagliflozin } & \multicolumn{2}{c}{ Saxagliptin } \\
\hline Conc $(\boldsymbol{\mu g} / \mathbf{m L})$ & Peak area & Conc $(\boldsymbol{\mu g} / \mathbf{m L})$ & Peak area \\
\hline 0 & 0 & 0 & 0 \\
25 & 1051797 & 12.5 & 154760 \\
50 & 2031439 & 25 & 306194 \\
75 & 2942756 & 37.5 & 473244 \\
100 & 3811209 & 50 & 618538 \\
125 & 4743235 & 62.5 & 771469 \\
150 & 5666991 & 75 & 914419 \\
\hline
\end{tabular}

Table 3: System precision table of Dapagliflozin and Saxagliptin

\begin{tabular}{ccc}
\hline S. No & Area of Dapagliflozin & Area of Saxagliptin \\
\hline 1. & 3824237 & 616187 \\
2. & 3867517 & 614797 \\
3. & 3842883 & 614559 \\
4. & 3871852 & 615571 \\
5. & 3809148 & 617990 \\
6. & 3837088 & 615398 \\
Mean & 3842121 & 615750 \\
S.D & 24338.7 & 1240.3 \\
\%RSD & 0.6 & 0.2 \\
\hline
\end{tabular}

Table 4: Repeatability table of Dapagliflozin and Saxagliptin

\begin{tabular}{ccc}
\hline S. No & Area of Dapagliflozin & Area of Saxagliptin \\
\hline 1. & 3809246 & 611715 \\
2. & 3827051 & 613026 \\
3. & 3855433 & 615976 \\
4. & 3823260 & 616734 \\
5. & 3812089 & 618397 \\
6. & 3855001 & 611720 \\
Mean & 3830347 & 614595 \\
S.D & 20380.5 & 2827.0 \\
\%RSD & 0.5 & 0.5 \\
\hline
\end{tabular}

Table 5: Intermediate precision table of Dapagliflozin and Saxagliptin

\begin{tabular}{ccc}
\hline S. No & Area of Dapagliflozin & Area of Saxagliptin \\
\hline 1. & 3929409 & 1088672 \\
2. & 3904203 & 1095698 \\
3. & 3925132 & 1099574 \\
4. & 3914937 & 1095548 \\
5. & 3926559 & 1097245 \\
6. & 3926559 & 1101211 \\
Mean & 3921133 & 1096325 \\
S.D & 9678.7 & 4355.2 \\
\%RSD & 0.2 & 0.4 \\
\hline
\end{tabular}

Intermediate precision: Average area, standard deviation and \% RSD were calculated for two drugs and obtained as $0.2 \%$ and $0.4 \%$ respectively for Dapagliflozin and Saxagliptin (Table 5).

Accuracy: Three levels of Accuracy samples were prepared by standard addition method. Triplicate injections were given for each level of accuracy and mean \% Recovery was obtained as $98.98 \%$ and $98.72 \%$ for Dapagliflozin and Saxagliptin respectively (Table 6 \& 7, Fig. 7, 8 \& 9).

Sensitivity: Table 8 .

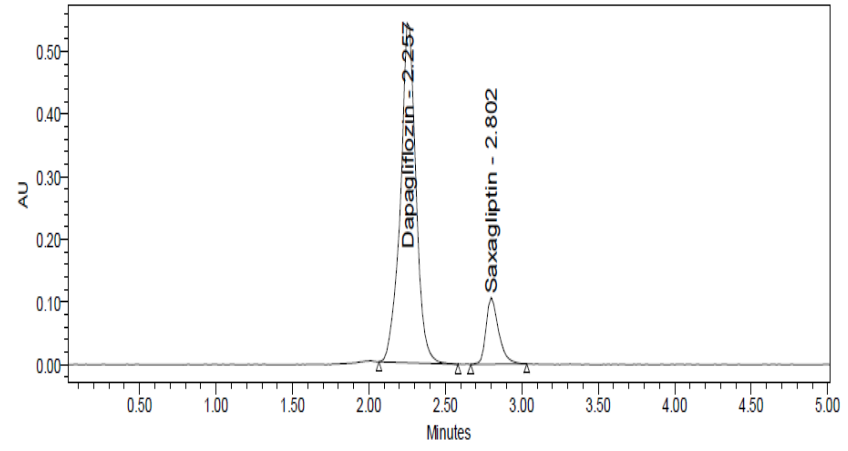

Fig. 4: System suitability chromatogram

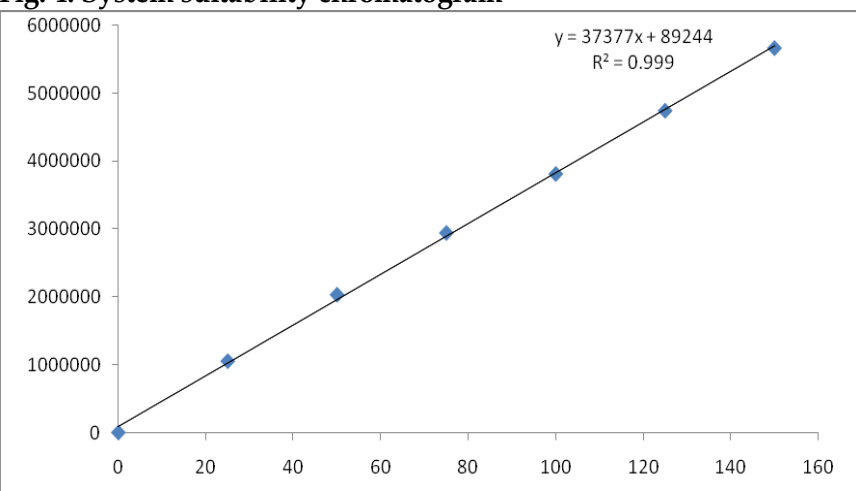

Fig. 5: Calibration curve of Dapagliflozin

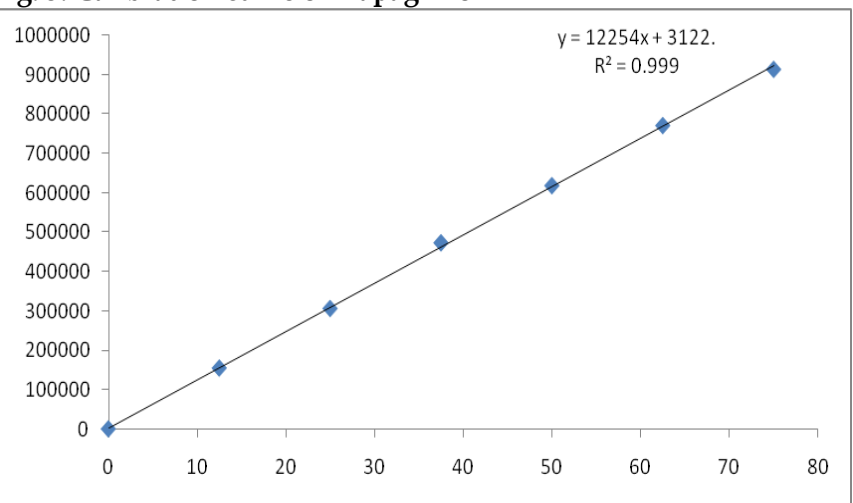

Fig. 6: Calibration curve of Saxagliptin

Table 6: Accuracy table of Dapagliflozin

\begin{tabular}{ccccc}
\hline $\begin{array}{c}\text { \% } \\
\text { Level }\end{array}$ & $\begin{array}{c}\text { Amount } \\
\text { Spiked } \\
(\boldsymbol{\mu g} / \mathbf{m L})\end{array}$ & $\begin{array}{c}\text { Amount } \\
\text { recovered } \\
(\boldsymbol{\mu g} / \mathbf{m L})\end{array}$ & \% Recovery & $\begin{array}{c}\text { Mean } \\
\text { \%Recovery }\end{array}$ \\
\hline \multirow{3}{*}{$50 \%$} & 50 & 49.4969366 & 98.99 & \\
& 50 & 49.1189769 & 98.24 & \\
& 50 & 49.2521337 & 98.50 & \\
$100 \%$ & 100 & 99.2575648 & 99.26 & \\
& 100 & 99.6980228 & 99.70 & $98.98 \%$ \\
& 100 & 99.8285844 & 99.83 & \\
$150 \%$ & 150 & 148.790138 & 99.19 & \\
& 150 & 148.622308 & 99.08 & \\
\hline
\end{tabular}


B. Reddy Padmaja et al. / A Highly Validated RP-HPLC Method Development for the Simultaneous.

Table 7: Accuracy table of Saxagliptin

\begin{tabular}{ccccc}
\hline $\begin{array}{c}\text { \% } \\
\text { Level }\end{array}$ & $\begin{array}{c}\text { Amount } \\
\text { Spiked } \\
(\boldsymbol{\mu} \mathbf{g} / \mathbf{m L})\end{array}$ & $\begin{array}{c}\text { Amount } \\
\text { recovered } \\
(\boldsymbol{\mu} \mathbf{g} / \mathbf{m L})\end{array}$ & \% Recovery & $\begin{array}{c}\text { Mean } \\
\text { \%Recovery }\end{array}$ \\
\hline \multirow{3}{*}{$50 \%$} & 25 & 24.6866329 & 98.75 & \\
& 25 & 24.7202546 & 98.88 & \\
& 25 & 24.5829933 & 98.33 & \\
$100 \%$ & 50 & 49.0874816 & 98.17 & \\
& 50 & 49.1721071 & 98.34 & \\
& 50 & 49.61433 & 99.23 & \\
$150 \%$ & 75 & 73.9643382 & 98.62 & \\
& 75 & 74.185164 & 98.91 & \\
\hline
\end{tabular}

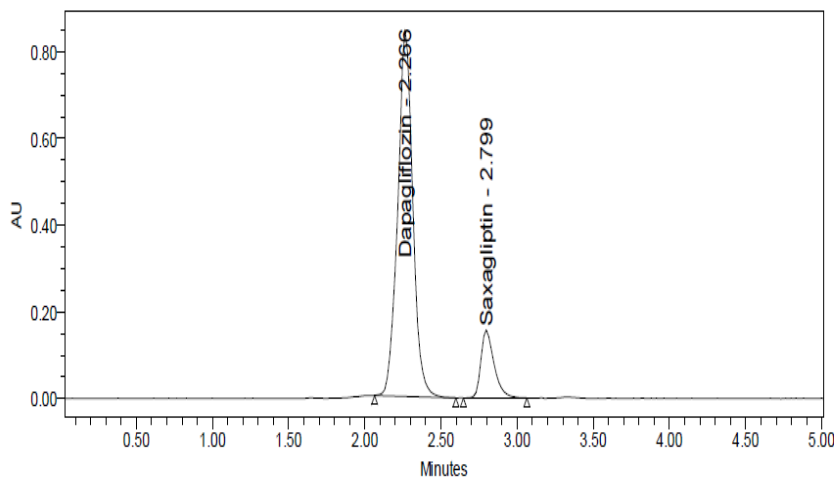

Fig. 7: Accuracy $50 \%$ chromatogram of Dapagliflozin and Saxagliptin

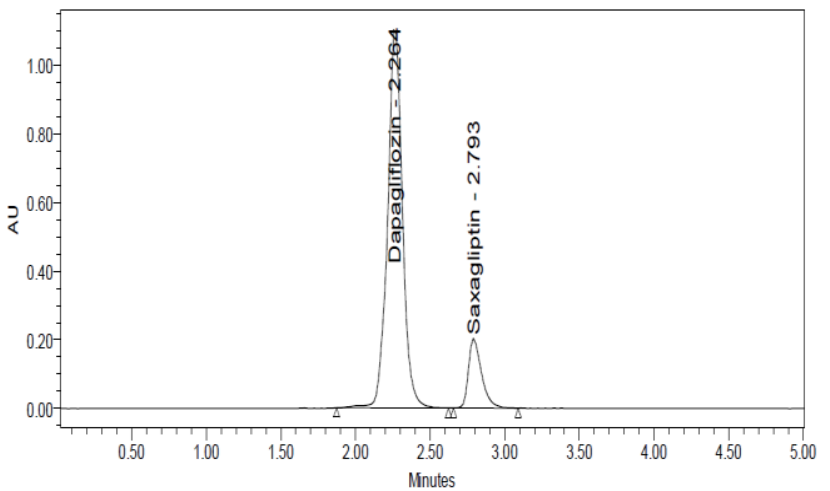

Fig. 8: Accuracy 100\% chromatogram of Dapagliflozin and Saxagliptin

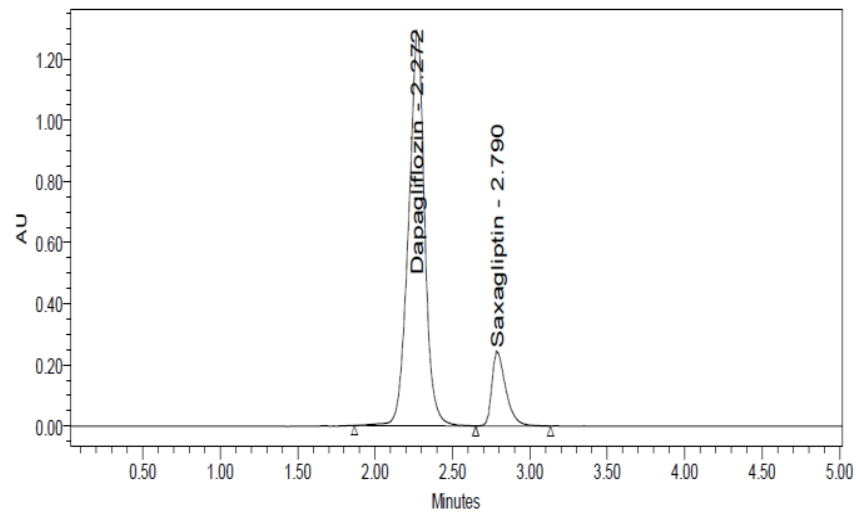

Fig. 9: Accuracy 150\% chromatogram of Dapagliflozin and Saxagliptin

Table 8: Sensitivity table of Dapagliflozin and Saxagliptin

\begin{tabular}{ccc}
\hline Molecule & LOD & LOQ \\
\hline Dapagliflozin & 0.20 & 0.60 \\
Saxagliptin & 0.26 & 0.79 \\
\hline
\end{tabular}

Table 9: Robustness data for Dapagliflozin and Saxagliptin

\begin{tabular}{cccc}
\hline S. No & Condition & $\begin{array}{c}\text { \%RSD of } \\
\text { Dapagliflozin }\end{array}$ & $\begin{array}{c}\text { \%RSD of } \\
\text { Saxagliptin }\end{array}$ \\
\hline 1 & $\begin{array}{c}\text { Flow rate (-) } 0.9 \\
\text { ml/min }\end{array}$ & 1.4 & 0.5 \\
2 & $\begin{array}{c}\text { Flow rate (+) } 1.1 \\
\text { ml/min }\end{array}$ & 1.6 & 1.6 \\
\hline
\end{tabular}

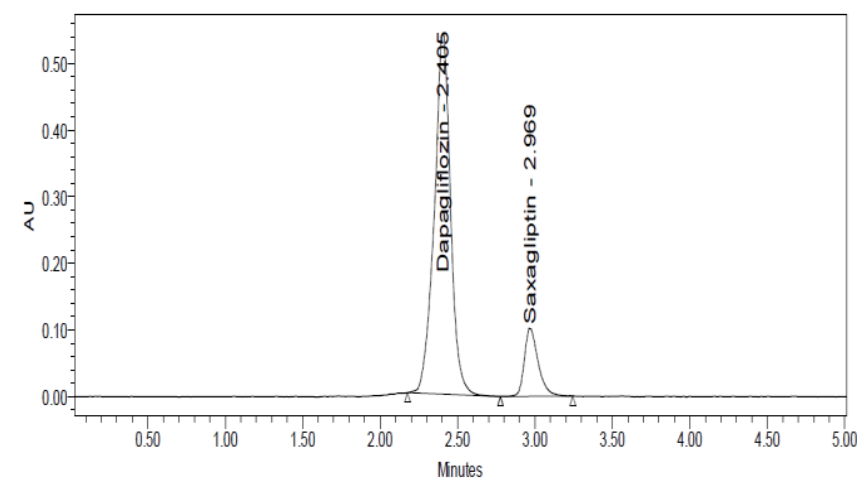

Fig. 10: Flow minus chromatogram of Dapagliflozin and Saxagliptin

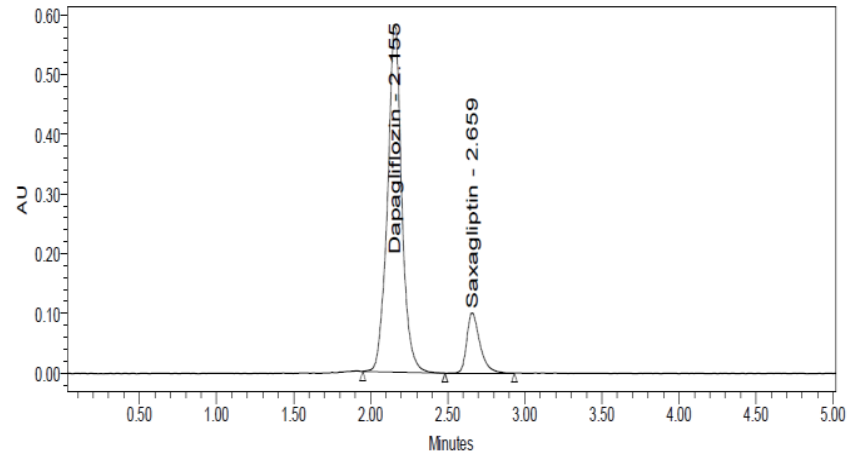

Fig. 11: Flow plus chromatogram of Dapagliflozin and Saxagliptin

Table 10: Assay data of Dapagliflozin

\begin{tabular}{cccc}
\hline S. No & Standard Area & Sample area & \% Assay \\
\hline 1 & 3824237 & 3809246 & 99.05 \\
2 & 3867517 & 3827051 & 99.51 \\
3 & 3842883 & 3855433 & 100.25 \\
4 & 3871852 & 3823260 & 99.41 \\
5 & 3809148 & 3812089 & 99.12 \\
6 & 3837088 & 3855001 & 100.23 \\
Avg & 3842121 & 3830347 & 99.59 \\
St dev & 24338.7 & 20380.5 & 0.5299 \\
\%RSD & 0.6 & 0.5 & 0.5 \\
\hline
\end{tabular}

\begin{tabular}{cccc}
\multicolumn{4}{l}{ Table 11: Assay data of Saxagliptin } \\
\hline S. No & Standard Area & Sample area & \% Assay \\
\hline 1 & 616187 & 611715 & 99.25 \\
2 & 614797 & 613026 & 99.46 \\
3 & 614559 & 615976 & 99.94 \\
4 & 615571 & 616734 & 100.06 \\
5 & 617990 & 618397 & 100.33 \\
6 & 615398 & 611720 & 99.25 \\
Avg & 615750 & 614595 & 99.71 \\
St dev & 1240.3 & 2827.0 & 0.46 \\
\%RSD & 0.2 & 0.5 & 0.46 \\
\hline
\end{tabular}

Robustness: Robustness conditions like Flow minus $(0.9 \mathrm{ml} / \mathrm{min})$, Flow plus $(1.1 \mathrm{ml} / \mathrm{min})$, was maintained and samples were injected in duplicate manner. System suitability parameters were not much affected and all the parameters were passed. \%RSD was within the limit (Table 9, Fig. 10 \& 11). 
Assay: AstraZeneca pharmaceuticals (Qtern), bearing the label claim Dapagliflozin 10mg, Saxagliptin 5mg. Assay was performed with the above formulation. Average \% Assay for Dapagliflozin and Saxagliptin obtained was $99.59 \%$ and $99.71 \%$ respectively (Table 10 $\& 11)$.

Degradation Studies: Degradation studies were performed with the formulation and the degraded samples were injected. Assay of the injected samples was calculated and all the samples passed the limits of degradation. Regarding the $\mathrm{pH}$ adjustment in mobile phase for the acid and base degradation studies have movement in retention time of drugs. But due to neutralized acid sample with $2 \mathrm{~N}$ Base solution and base sample with $2 \mathrm{~N}$ Acid solution there will be no change in retention time (Table 12 \& 13, Fig. 12, 13, 14 \& 15).

Table 12: Degradation data of Dapagliflozin

\begin{tabular}{ccccc}
\hline \multirow{2}{*}{ S. No } & $\begin{array}{c}\text { Degradation } \\
\text { Condition }\end{array}$ & $\begin{array}{c}\text { \% Drug } \\
\text { Degraded }\end{array}$ & $\begin{array}{c}\text { Purity } \\
\text { Angle }\end{array}$ & $\begin{array}{c}\text { Purity } \\
\text { Threshold }\end{array}$ \\
\hline 1 & Acid & 4.71 & 0.110 & 0.295 \\
2 & Alkali & 2.63 & 0.110 & 0.295 \\
3 & Oxidation & 1.91 & 0.286 & 0.619 \\
4 & Thermal & 0.87 & 0.286 & 0.315 \\
\hline
\end{tabular}

Table 13: Degradation data of Saxagliptin

\begin{tabular}{ccccc}
\hline S. No & $\begin{array}{c}\text { Degradation } \\
\text { Condition }\end{array}$ & $\begin{array}{c}\text { \% Drug } \\
\text { Degraded }\end{array}$ & $\begin{array}{c}\text { Purity } \\
\text { Angle }\end{array}$ & $\begin{array}{c}\text { Purity } \\
\text { Threshold }\end{array}$ \\
\hline 1 & Acid & 4.98 & 0.259 & 0.971 \\
2 & Alkali & 2.69 & 0.060 & 0.939 \\
3 & Oxidation & 1.85 & 0.619 & 0.747 \\
4 & Thermal & 0.54 & 0.619 & 0.747 \\
\hline
\end{tabular}

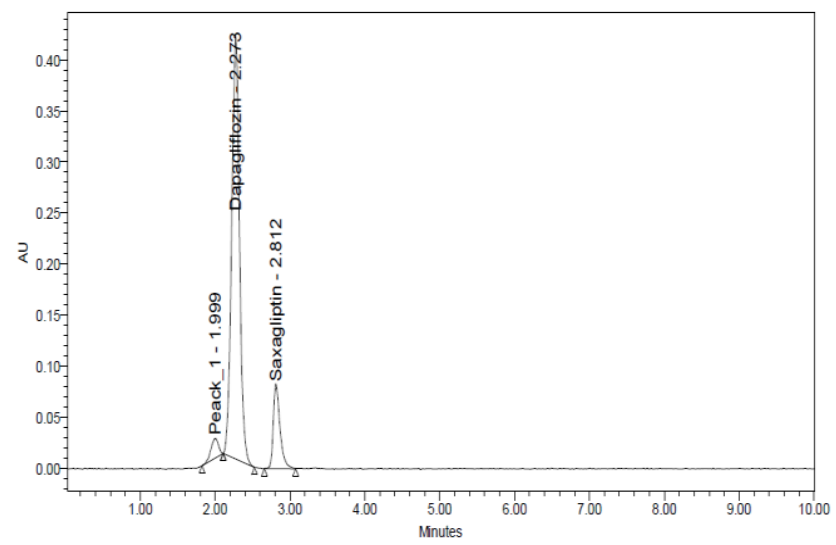

Fig. 12: Acid chromatogram of Dapagliflozin and Saxagliptin

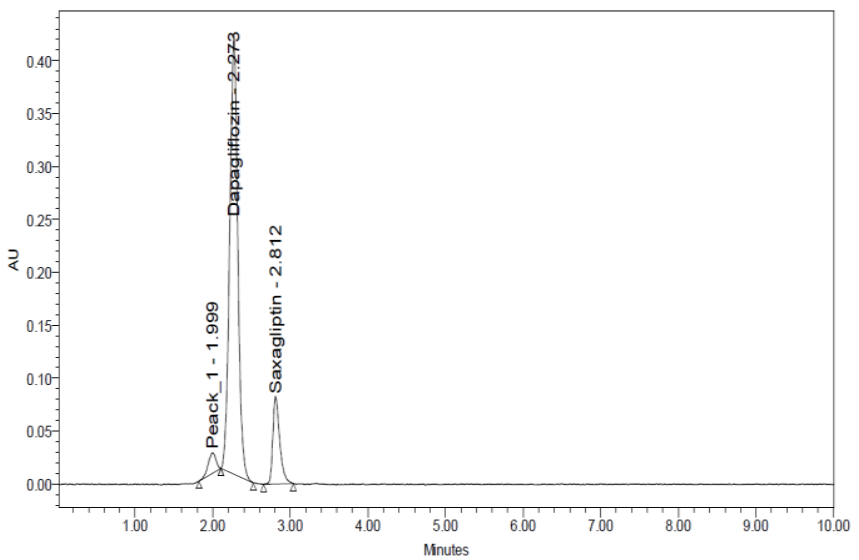

Fig. 13: Base chromatogram of Dapagliflozin and Saxagliptin

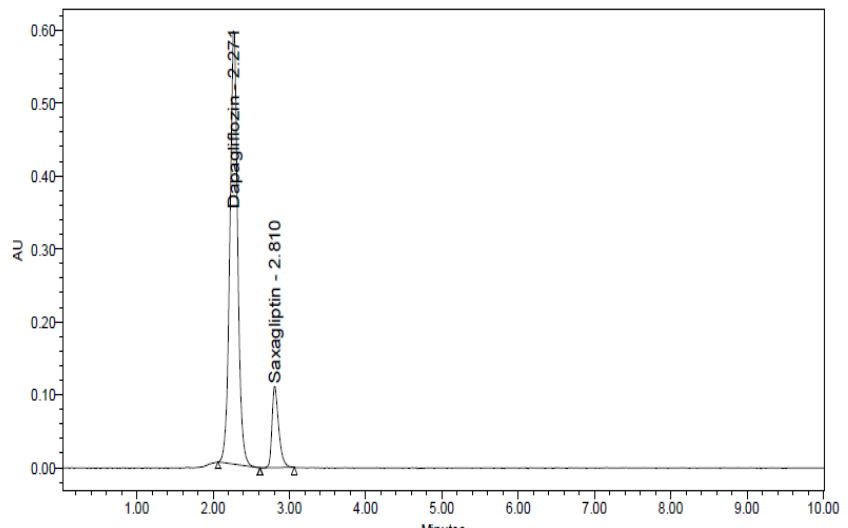

Fig. 14: Peroxide chromatogram of Dapagliflozin and Saxagliptin

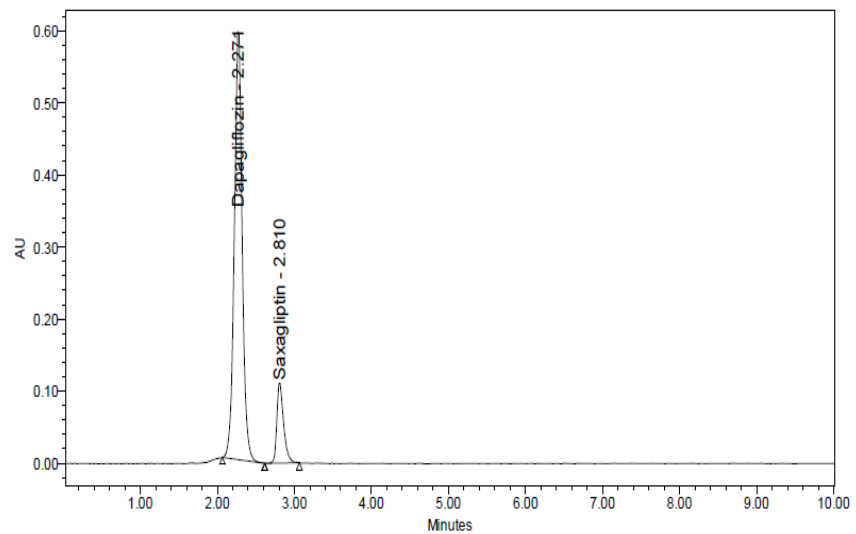

Fig. 15: Thermal chromatogram of Dapagliflozin and Saxagliptin

A simple, Accurate, precise method was developed for the simultaneous estimation of the Dapagliflozin and Saxagliptin in Tablet dosage form. The RP-HPLC method developed and validated allows a simple and rapid quantitative determination of Dapagliflozin and Saxagliptin in tablet dosage forms. All the validation parameters were found to be within the limits according to ICH guidelines. The proposed method was found to be simple, accurate and specific for the drugs of interest irrespective of the excipients present and the short retention times allows the analyst to analyze number of samples in a short period. The method developed was found to be simple, accurate, precise, rugged, robust and stable under forced degradation conditions. So the established method can be successfully applied for the routine analysis for marketed formulations.

\section{REFERENCES}

1. Bristol-Myers Squibb: FORXIGA (Dapagliflozin Propanediol Monohydrate) product information. Noble Park, VIC: BristolMyers Squibb Pty. Ltd., 2012.

2. List JF, Woo V, Morales E, Tang W, Fiedorek FT. Sodiumglucose cotransport inhibition with Dapagliflozin in type 2 diabetes. Diabetes Care. 2009; 32:650-57.

3. Kalra S, Ghosh S, Aamir AH, Ahmed MT, Amin MF, Bajaj S, et al. Safe and pragmatic use of sodium-glucose cotransporter 2 inhibitors in type 2 diabetes mellitus: South Asian Federation of Endocrine Societies consensus statement. Indian J Endocrinol Metab. 2017; 21(1): 210-230.

4. Mikhail N. Place of sodium-glucose co-transporter type 2 inhibitors for treatment of type 2 diabetes. World J Diabetes 2014; 5(6): 854-859. 
5. Hinnen D. Glucuretic effects and renal safety of Dapagliflozin in patients with type 2 diabetes. Ther Adv Endocrinol Metab. 2015; 6(3): 92-102.

6. Kilov G, Leow S, Thomas M. Clinical SGLT2 inhibition with Dapagliflozin A novel approach for the management of type 2 diabetes. AFP 2013; 42(10):706-710.

7. Chao EC. Do SGLT-2 Inhibitors: A New Mechanism for Glycemic Control. Clin Diabetes 2014; 32(1): 4-11.

8. Vivian EM. Sodium-glucose co-transporter 2 (SGLT2) inhibitors: a growing class of antidiabetic agents. Drugs Context. 2014; 3: 212264.

9. Bays H. Sodium Glucose Co-transporter Type 2 (SGLT2) Inhibitors: Targeting the Kidney to Improve Glycemic Control in Diabetes Mellitus. Diabetes Ther. 2013; 4(2): 195220.

10. Pathak R, Bridgeman MB. Dipeptidyl Peptidase-4 (DPP-4) Inhibitors in the Management of Diabetes. P T. 2010; 35(9): 509-513.

11. Crepaldi G, Carruba M, Comaschi M, Del Prato S, Frajese G, Paolisso G. Dipeptidyl peptidase 4 (DPP-4) inhibitors and their role in Type 2 diabetes management. J Endocrinol Invest. 2007; 30(7):610-4.

12. ICH Harmonised Tripartite Guideline, validation of analytical procedures: Text methodology, Q2 (R1) (2005). International Conference on Harmonization, Geneva, pp: 113.
13. Debata J, Kumar S, Jha SK, Khan A. A New RP-HPLC Method Development and Validation of Dapagliflozin in Bulk and Tablet Dosage Form. International Journal of Drug Development and Research. 2017; 9:48-51.

14. Yunoos M, Sankar G. A validated stability indicating highperformance liquid chromatographic method for simultaneous determination of Metformin $\mathrm{HCl}$ and Dapagliflozin in bulk drug and tablet dosage form. Asian J Pharm Clin Res. 2015; 8(3): 320-326.

15. Prasad PBN, Satyanaryana K, Krishnamohan G. Development and Validation of a Method for Simultaneous Determination of Metformin and Saxagliptin in a Formulation by RP-HPLC. American Journal of Analytical Chemistry. 2015; (6): 841-850.

16. Patel PD, Pandya SS. Validated RP - HPLC Method for Simultaneous Estimation of Dapagliflozin and Saxagliptin Hydrochloride in Tablet Dosage Form. International Journal for Pharmaceutical Research Scholars. 2018; 7 (1): 9-15.

17. Singh N, Bansal P, Maithani M, Chauhan Y. Development and validation of a stability indicating RP-HPLC method for simultaneous determination of Dapagliflozin and Saxagliptin in fixed-dose combination. New J. Chem. 2018; 42: 2459-2466.

18. Deepan T, Dhanaraju MD. Stability indicating HPLC method for the simultaneous determination of Dapagliflozin and Saxagliptin in bulk and tablet dosage form. Curr. Issues Pharm. Med. Sci. 2018; 31(1):39-43.

HOW TO CITE THIS ARTICLE: Reddy Padmaja B, Sivagami B, Sireesha R, Chandrasekar R, Niranjan babu M. A Highly Validated RP-HPLC Method Development for the Simultaneous Estimation of Dapagliflozin and Saxagliptin in Tablet Dosage Forms. Int. J. Pharm. Sci. Drug Res. 2018; 10(5): 372-378. DOI: 10.25004/IJPSDR.2018.100503 